\title{
DEGRADABILITAS NUTRIEN BAGASSE AMOFER PADA DOMBA SECARA In Sacco
}

\author{
Nurahman, M. E. ${ }^{1}$, E. Pangestu ${ }^{2}$ dan F. Wahyono ${ }^{2}$ \\ 1) Mahasiswa Fakultas Peternakan Dan Pertanian Universitas Diponegoro \\ Kampus drh. Soejono Koesoemowardojo Tembalang Semarang 50275 \\ E-mail: mamanalfaiz@gmail.com \\ ${ }^{2)}$ Fakultas Peternakan dan Pertanian, Universitas Diponegoro \\ Kampus drh. R. Soejono Kusumowardojo Tembalang, Semarang 50275
}

Diterima: 26 Juli 2016 Disetujui: 25 Oktober 2016

\begin{abstract}
ABSTRAK
Penelitian dilakukan untuk mengetahui degradabilitas nutrien bahan kering, bahan organik dan neutral detergent fibre pada bagasse amofer dan bagasse tanpa amofer pada domba secara in sacco. Materi penelitian adalah dua ekor domba jantan berfistula, ransum standar, bagasse amofer dan bagasse tanpa amofer. Degradabilitas dilakukan menggunakan metode in sacco. Sampel dimasukan dalam kain nilon kemudian diinkubasikan pada 7 titik waktu $(0,3,6,12,24,48$ dan 72 jam). Parameter yang diteliti adalah degradasi bahan kering (BK), bahan organik (BO) dan neutral detergent fibre (NDF) dihitung dengan persamaan eksponensial, $\mathrm{P}=\mathrm{a}+\mathrm{b}\left(1-\exp ^{-\mathrm{ct}}\right)$. Uji $\mathrm{t}$ dilakukan untuk mengetahui ada tidaknya perbedaan diantara kedua perlakuan bagasse. Hasil penelitan menunjukan bahwa perlakuan bagasse amofer berpengaruh nyata $(\mathrm{P}<0,05)$ lebih tinggi dibanding bagasse tanpa amofer terhadap degradasi BK, BO, dan NDF. Simpulan penelitian yaitu pengolahan bagasse amoniasi dan fermentasi mampu meningkatkan degradabilitas nutrien bahan kering, bahan organik dan neutral detergent fibre.
\end{abstract}

Kata kunci: $B K, B O, N D F$, bagasse, amofer

\section{IN SACCO NUTRIENT DEGRADABILITY OF BAGASSE AMOFER ON THE SHEEP}

\begin{abstract}
The study was conducted to determine the nutrient degradability of dry matter, organic matter and neutral detergent fiber on amofer bagasse and bagasse without amofer on the sheep in sacco. The research material are two fistula sheep, standard ration, bagasse amofer and bagasse without amofer. Degradability performed using methods in sacco. Samples included in the nylon fabric then incubated in seven time points $(0,3,6,12$, 24, 48 and 72 hours). Parameters studied were the degradation of dry matter (DM), organic matter $(B O)$ and neutral detergent fiber $(N D F)$ is calculated by an exponential equation, $P=a+b$ (1-exp-ct). T tests were conducted to determine whether there were a difference between the two treatment bagasse. Results showed that treatment of bagasse amofer significant $(P<0.05)$ higher than the bagasse without amofer against degradation $B K, B O$, and NDF. Conclusions of research showed that bagasse ammoniation processing
\end{abstract}


and fermentation can improve nutrient degradability of dry matter, organic matter and neutral detergent fiber.

Keywords: DM, OM, NDF, bagasse, amofer

\section{PENDAHULUAN}

Produktivitas ternak ditentukan oleh kualitas suatu pakan, salah satunya adalah hijauan pakan. Kualitas pakan mencakup kandungan berbagai zat gizi dan nutrisi, yaitu energi, protein, vitamin, mineral serta zat anti nutrisi lainnya. Hijauan merupakan sumber pakan utama ternak ruminansia yang berfungsi sebagai sumber nutrisi, mencakup sumber energi, protein, vitamin dan mineral. Selain itu, hijauan merupakan salah satu sumber serat bagi ternak ruminansia. Sumber serat dapat berupa hijauan (rumput dan leguminosa), limbah pertanian dan limbah perkebunan (Chuzaemi dan Hartutik, 1998).

Bagasse bisa dimanfaatkan karena berpotensi menyediakan bahan pakan alternatif sumber serat yang bisa dimanfaatkan ternak ruminansia. Bagasse memiliki kandungan serat kasar yang tinggi dan protein kasar yang rendah. Faktor pembatas dalam penggunaan bagasse sebagai pakan adalah kandungan lignoselulosa yang tinggi sehingga nilai gizinya rendah (Soejono et al., 1985). Rekayasa teknologi pengolahan pakan untuk meningkatkan kualitas nutrisi bagasse adalah amoniasi dan fermentasi. Proses amoniasi akan melemahkan ikatan lignoselulosa bagasse serta fermentasi dapat menurunkan kadar serat kasar dan meningkatkan kadar protein kasar. (Wolayan, 1998).

Metode in sacco dapat digunakan untuk menentukan degradabilitas bagasse. Metode in sacco adalah metode yang dilaksanakan dengan memasukkan pakan penelitian kedalam kantong berpori yang diikatkan dan ditempatkan ke dalam rumen ternak yang hidup selama waktu tertentu (Uden dan Van Soest, 1984).

Tujuan penelitian adalah untuk mengetahui degradabilitas bahan kering, bahan organik dan neutral detergent fibre bagasse amofer secara in sacco. Hipotesis penelitian adalah pengolahan amoniasi dan fermentasi pada bagasse mampu meningkatkan degradasi bahan kering (BK), bahan organik (BO) dan neutral detergent fibre (NDF).

\section{MATERI DAN METODE}

Penelitian mengenai degradabilitas nutrien bagasse amofer pada domba secara in sacco dilaksanakan pada bulan JanuariMaret 2015 di Fakultas Peternakan dan Pertanian Universitas Diponegoro, Semarang.

\section{Materi}

Materi yang digunakan adalah 2 ekor domba lokal berfistula umur 2 tahun, ransum standar. Bahan pakan yang digunakan adalah bagasse amofer dan bagasse tanpa amofer.

Peralatan yang digunakan yaitu mesin cuci, kandang individu berukuran 100x150 $\mathrm{cm}$ dilengkapi dengan palung pakan, kantong nilon berukuran 2x6 cm berporositas 40-50 $\mu \mathrm{m}$ dan benang nilon serta peralatan analisis proksimat. 


\section{Metode}

Penelitian menggunakan Uji $\mathrm{T}$ dengan 2 perlakuan dan 4 ulangan dengan pola sebagai berikut :

\begin{tabular}{|c|c|c|c|}
\hline T1U1 & T1U2 & T1U3 & T1U4 \\
\hline T2U1 & T2U2 & T2U3 & T2U4 \\
\hline
\end{tabular}

Penelitian dilaksanakan dengan 3 menggunakan starter komersial Biostarter tahap yaitu tahap persiapan, tahap uji sebanyak $6 \%$ bahan kering dengan lama degradabilitas, dan tahap analisis data. Proses amoniasi dilakukan menurut Komar (1984) dan Prastyawan et al., (2012) yaitu metode pemanasan $60^{\circ} \mathrm{C}$ selama 2 hari dengan kadar amonia sebanyak $6 \%$ bahan kering lalu dilanjutkan fermentasi pemeraman 4 minggu.

Komposisi dan kandungan nutrien ransum standar, kandungan nutrien bagasse amofer dan bagasse tanpa amofer disajikan pada Tabel 1 dan Tabel 2:

Tabel 1. Komposisi dan Kandungan Nutrien Ransum Standar

\begin{tabular}{lclc}
\hline \hline Bahan pakan & Standar & Nutrien & Standar \\
\hline & $---\%---$ & & $---\%---$ \\
R. Gajah & 70 & BK & 34,41 \\
Dedak & 9 & BO & 86,56 \\
B. Kedelai & 11 & PK & 12,86 \\
Onggok & 4 & LK & 2,60 \\
Urea & 1 & SK & 26,20 \\
Tetes & 5 & TDN & 60,06 \\
- & - & BETN & 56,93 \\
- & - & NDF & 59,96 \\
- & - & Isi Sel & 40,04 \\
Jumlah & 100 & KH non struktural & 23,17 \\
\hline
\end{tabular}

Tabel 2. Komposisi Kandungan Nutrien Bagasse Amofer dan Bagasse Tanpa Amofer

\begin{tabular}{|c|c|c|}
\hline \multirow[t]{2}{*}{ Nutrien } & \multicolumn{2}{|c|}{ Perlakuan } \\
\hline & Bagasse Amofer (T1) & Bagasse Tanpa Amofer (T2) \\
\hline & \multicolumn{2}{|c|}{ - } \\
\hline BK & 88,73 & 93,09 \\
\hline BO & 88,84 & 96,65 \\
\hline PK & 8,79 & 1,74 \\
\hline SK & 43,24 & 38,22 \\
\hline LK & 3,06 & 2,05 \\
\hline BETN & 35,71 & 56,62 \\
\hline TDN & 46,65 & 49,49 \\
\hline $\mathrm{NDF}$ & 83,39 & 89,06 \\
\hline
\end{tabular}

Menimbang sampel per kantong sebanyak $3 \mathrm{~g}$, masukan kelereng sebagai pemberat dan kantong diikat dengan benang nilon. Kantong nylon berisi sampel bagasse dimasukan ke dalam rumen bagian ventral dimasukan satu jam sebelum pemberian pakan. Periode inkubasi dengan menggunakan tujuh interval waktu yaitu 0 ,
3, 6, 12, 24, 48, dan 72 jam (Flachowsky dan Schneider, 1992).

Sampel yang telah diinkubasi di dalam rumen diambil sesuai dengan waktu inkubasi dan segera dicuci dengan mesin cuci selama 3 menit dengan air yang terus mengalir. Selanjutnya dimasukan ke dalam oven dengan suhu $60^{\circ} \mathrm{C}$ selama 48 jam, 
kemudian dianalisis kandungan $\mathrm{BK}, \mathrm{BO}$ dan NDF.

Degradasi BK, BO dan NDF dihitung dalam persamaan eksponensial sesuai model Ørskov dan McDonald (1979) sebagai berikut:

$$
\begin{aligned}
& \mathrm{P}(\%)=a+b\left(1-\exp \left({ }^{-c t}\right)\right) \\
& \text { DT }=a+\frac{(b \times c)}{(c+k)}
\end{aligned}
$$

Keterangan:

P : Degradasi pada waktu t (\%)

DT : Degradasi Teori

a : fraksi yang mudah larut

b : fraksi potensial untuk degradasi

c : laju degradasi fraksi b

$\mathrm{k} \quad$ : konstanta $(0,05 /$ jam $)$
Parameter penelitian meliputi degradasi BK, BO dan NDF pada bagasse amofer (T1) dan bagasse tanpa amofer (T2). Analisis data penelitian menggunakan uji $\mathrm{T}$ (T-test).

\section{HASIL DAN PEMBAHASAN}

Berdasarkan Ilustrasi 1. diketahui bahwa kinetika degradabilitas bagasse amofer (T1) dan bagasse tanpa amofer (T2) mengalami peningkatan nilai degradasi. Semakin lama pakan diinkubasika akan memberi kesempatan bagi mikrobia untuk mendegradasi nutrien yang terkandung di dalam bagasse. Ginting (2005) menyatakan bahwa peningkatan waktu inkubasi berarti mikroba rumen mempunyai waktu lebih lama untuk kontak dengan material dalam kantong sehingga tingkat degradasi akan lebih tinggi.
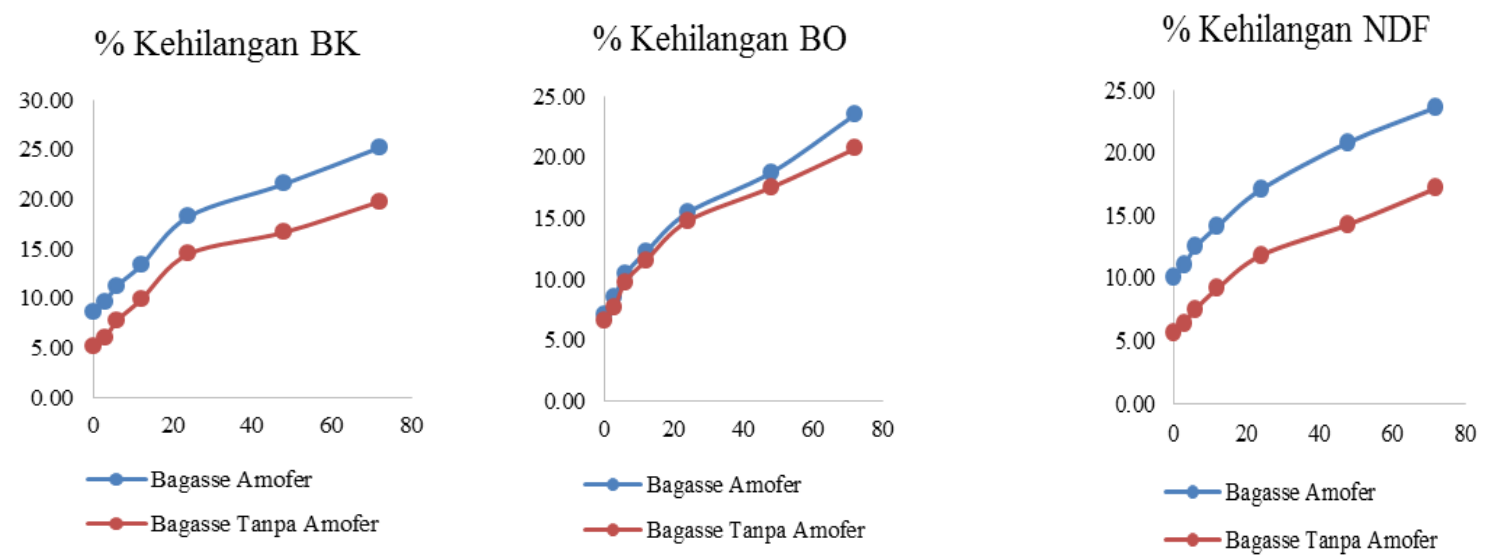

Ilustrasi 1. Kinetika Degradabilitas Nutrien Bagasse

\section{Degradasi Bahan Kering (BK)}

Rerata nilai fraksi a, b, c, dan DT degradasi BK penelitian disajikan pada Tabel 3 berikut :

Tabel 3. Rerata fraksi a, b, c, dan DT degradasi BK

\begin{tabular}{lcc}
\hline & \multicolumn{2}{c}{ Perlakuan } \\
\cline { 2 - 3 } Parameter & Bagasse Amofer (T1) & Bagasse Tanpa Amofer (T2) \\
\hline Fraksi a & $4.61^{\mathrm{a}}$ & $2.41^{\mathrm{b}}$ \\
Fraksi b & $16.95^{\mathrm{a}}$ & $14.27^{\mathrm{b}}$ \\
Laju c & $3.22^{\mathrm{a}}$ & $3.45^{\mathrm{a}}$ \\
DT & $11.24^{\mathrm{a}}$ & $8.24^{\mathrm{b}}$ \\
\hline
\end{tabular}


Hasil uji t menunjukkan fraksi a, fraksi b dan degradasi teori (DT) bagasse amofer (T1) dan bagasse tanpa amofer (T2) berbeda nyata $(\mathrm{P}<0,05)$. Degradabilitas bagasse amofer (T1) lebih besar dibandingkan bagasse tanpa amofer (T2). Hal tersebut disebabkan oleh kandungan nutrien dari masing-masing perlakuan berbeda, sehingga kemampuan mikrobia rumen dalam mendegradasi pakan perlakuan juga berbeda. Baiti (2012) menyatakan bahwa fraksi a merupakan fraksi yang mudah larut baik di dalam rumen maupun pada saat pencucian awal. Komponen nutrien yang termasuk fraksi a dalam degradasi BK antara lain pati, gulagula sederhana dan sebagian protein. Widiawati et al., (2007) menyatakan bahwa angka degradasi BK di dalam rumen sangat dipengaruhi oleh jenis pakan.

Nilai DT tergantung dari nilai $a, b$, dan laju degradasi fraksi b (c). Semakin besar kandungan mudah larut maka nilai degradasi teori semakin besar akan tetap fraksi potensial terdegradasi dapat mempengaruhi rendahnya nilai laju degradasi dan nilai degradasi teori. Ørskov et al. (1997) mengatakan bahwa tingginya nilai degradasi fraksi a dan fraksi $b$ menyebabkan tingkat degradabilitas bahan pakan tinggi.

Fraksi a, b, dan degradasi teori (DT) bagasse tanpa amofer (T2) memiliki nilai degradasi lebih rendah dibandingkan dengan nilai degradasi bagasse amofer (T1). Hal ini karena bagasse memiliki kandungan serat kasar yang tinggi dan protein kasar yang rendah. Faktor pembatas dalam penggunaan ampas tebu sebagai pakan adalah tingginya kandungan lignoselulosa sehingga nilai gizinya rendah (Soejono et al., 1985). McDonald et al. (1994) menyatakan bahwa komposisi kimia bahan merupakan salah satu faktor yang menentukan tingkat degradasi dan kecernaan bahan makanan dalam rumen.

Nilai c pada kedua perlakuan tidak berbeda nyata $(\mathrm{P}>0,05)$, karena mempunyai nilai kehilangan yang hampir sama, artinya fraksi b yang di degradasi mikrobia rumen mempunyai tingkat kesulitan yang sama.

\section{Degradasi Bahan Organik (BO)}

Rerata nilai fraksi a, b, c, dan DT degradasi BO penelitian disajikan pada Tabel 4 berikut :

Tabel 4. Rerata fraksi a, b, c, dan DT degradasi BO

\begin{tabular}{lcc}
\hline \hline & & \\
Parameter & Bagasse Amofer (T1) & Berlakuan \\
\cline { 2 - 3 } Fraksi a & $1.77^{\mathrm{a}}$ & $4.79^{\mathrm{b}}$ \\
Fraksi b & $17.00^{\mathrm{a}}$ & $12.76^{\mathrm{b}}$ \\
Laju c & $2.04^{\mathrm{a}}$ & $3.83^{\mathrm{b}}$ \\
DT & $6.70^{\mathrm{a}}$ & $10.32^{\mathrm{b}}$ \\
\hline
\end{tabular}

Hasil analisis bagasse amofer (T1) dan bagasse tanpa amofer (T2) menunjukkan hasil yang berbeda nyata $(\mathrm{P}<0,05)$. Hal tersebut disebabkan oleh kandungan masing-masing perlakuan berbeda, sehingga kemampuan mikrobia rumen dalam mendegradasi bahan pakan perlakuan juga berbeda. Hal ini sesuai dengan pendapat Goering dan Van Soest (1970) yang menyatakan bahwa degradasi BO bahan pakan dipengaruhi oleh adanya lignin dan silika yang terdapat di dalam dinding sel secara bersama-sama yang akan membentuk senyawa kompleks dengan selulosa dan hemiselulosa. 
Hasil analisis kedua perlakuan (hemiselulosa dan selulosa). Nilai c berbeda nyata $(\mathrm{P}<0,05)$ sehingga fraksi a, merupakan laju yang besarnya dipengaruhi fraksi b, nilai c dan degradasi teori (DT) oleh komponen fraksi $b$ sedangkan pada Tabel 3 menunjukan perbedaan yang degradasi terori (DT) tergantung dari nilai nyata $(\mathrm{P}<0,05)$. Nilai a merupakan fraksi $\mathrm{a}, \mathrm{b}$, dan laju degradasi fraksi $\mathrm{b}(\mathrm{c})$. Goering yang mudah larut, nilai b adalah fraksi dan Van Soest (1970) menyatakan bahwa pakan potensial terdegradasi, sedangkan degradasi BO bahan pakan dipengaruhi nilai $\mathrm{c}$ adalah laju degradasi fraksi $\mathrm{b}$. Nilai a oleh adanya lignin dan silika yang terdapat berupa komponen penyusun isi sel seperti di dalam dinding sel secara bersama-sama pati, protein, lemak dan mineral yang larut. yang akan membentuk senyawa kompleks Nilai b merupakan komponen dinding sel dengan selulosa dan hemiselulosa.

\section{Degradasi Neutral Detergent Fibre (NDF)}

Rerata nilai fraksi a, b, c, dan DT degradasi NDF penelitian disajikan pada Tabel 5 berikut :

Tabel 5. Rerata fraksi a, b, c, dan DT degradasi NDF

\begin{tabular}{lcc}
\hline & \multicolumn{2}{c}{ Perlakuan } \\
\cline { 2 - 3 } Parameter & Bagasse Amofer (T1) & Bagasse Tanpa Amofer (T2) \\
\hline Fraksi a & $5.43^{\mathrm{a}}$ & $0.59^{\mathrm{b}}$ \\
Fraksi b & $15.42^{\mathrm{a}}$ & $13.71^{\mathrm{b}}$ \\
Laju c & $2.59^{\mathrm{a}}$ & $2.05^{\mathrm{a}}$ \\
DT & $10.68^{\mathrm{a}}$ & $4.57^{\mathrm{b}}$ \\
\hline
\end{tabular}

Hasil analisis menunjukkan bahwa bagasse amofer (T1) berpengaruh nyata $(\mathrm{P}<0,05)$ terhadap fraksi a, $\mathrm{b}$, dan degradsai teori (DT) pada masing-masing perlakuan. Hal tersebut disebabkan oleh kandungan masing-masing sampel berbeda, sehingga kemampuan mikrobia rumen dalam mendegradasi juga berbeda. Sesuai dengan pendapat Hakim (1992) bahwa kandungan NDF yang lebih mudah dicerna didalam rumen adalah hemiselulosa. Cullison (1979) menyatakan bahwa hemiselulosa termasuk dalam polisakarida yang mempunyai substansi lebih banyak didegradasi daripada selulosa, tetapi mempunyai degradasi yang lebih rendah daripada gula dan pati.

Berdasarkan analisis menunjukan bahwa bagasse amofer (T1) dan bagasse tanpa amofer (T2) tidak berpengaruh nyata $(\mathrm{P}>0,05)$ terhadap nilai c. Hal tersebut terjadi diduga disebabkan oleh kandungan selulosa dalam masing-masing perlakuan relatif sama sehingga kemampuan mikroba dalam mendegradasi bahan pakan tersebut juga akan sama nilainya. Hal ini sesuai dengan pernyataan Hakim (1992) bahwa komponen yang terdapat pada ADF yaitu selulosa, lignin dan silika. Tillman et al., (1991) menyatakan bahwa selulosa tidak mudah larut dan sulit untuk didegradasi.

\section{SIMPULAN DAN SARAN}

\section{Simpulan}

Pengolahan bagasse amoniasi dan fermentasi (amofer) mampu meningkatkan degradabilitas nutrien bahan kering, bahan organik dan neutral detergent fibre pada waktu inkubasi ke- 0, 3, 6, 12 dan 24 jam berdasarkan fraksi a, faksi b, nilai $\mathrm{c}$ dan DT. 
Saran

Penggunaan bagasse amofer dapat diberikan kepada ternak karena mempunyai nilai degradasi dan daya cerna yang lebih baik.

\section{DAFTAR PUSTAKA}

Baiti, L. Z. 2012. Degradasi Nutrien Ransum dengan Berbagai Level Pucuk Tebu pada Kambing Jawarandu secara In Sacco. Skripsi. Fakultas Peternakan Universitas Diponegoro, Semarang.

Chuzaemi, S. dan Hartutik. 1998. Ilmu Makanan Ternak Khusus. Fakultas Peternakan Universitas Brawijaya. Malang.

Cullison, A. E. 1979. Feeds and Feeding. Printice-Hall of India, New Delhi.

Flachowsky, G. and M. Schneider. 1992. Influence of various straw to concentrate ratio on in sacco dry matter degradability, feed intake and apparent digestibility in ruminants. Anim. Feed Sci. Tech. 38 : 199-217.

Ginting, P. S. 2005. Sinkronisasi degradasi protein dan energi dalam rumen untuk memaksimalkan produksi protein mikrobia. Wartazoa. 15 (1) : $1-10$.

Goering, H. K. and P. J. Van Soest. 1970. Forage Fiber Analysis. Agricultural Handbook No.379. Agricultural Research Service USDA, Washington DC.

Hakim, M. 1992. Laju Degradasi Protein Kasar dan Organik Setaria splendida, Rumput Lapangan dan Alang-alang (Imperate cylindrica) dengan Teknik In Sacco. Skripsi.
Fakultas Peternakan Institut Pertanian Bogor, Bogor.

Komar, A. 1984. Teknologi Pengolahan Jerami Padi sebagai Pakan Ternak. Cetakan Pertama. Yayasan Dian Grahita, Bandung.

McDonald, P, R. A. Edwards and J. F. D. Greenhalg. 1994.Animal Nutrition. $4^{\text {th }}$ Ed. Longman, London.

Ørskov, E. R. and W. J. Shand. 1997. Use of the nylon bag technique for protein and energy evaluation and for rumen environment studies in ruminant. Livestock Research for Rural Development. 9 (1): 8-12

Ǿrskov, E. R dan I. McDonald. 1979. The estimation of protein degradability in the rumen from In cabation measurements weight according to rate of passage. J. Agric. Sci. Comb., 92 : 499 - 503.

Prastyawan., R. M. P., B. I. M. Tampoebolon dan Surono. Peningkatan kualitas jagung melalui teknologi amoniasi dan fermentasi (amofer) terhadap kecernaan bahan kering dan bahan organic serta protein total secara in vitro. Animal Agriculture Journal. 1 (1) : 611 621

Soejono, M., R. Utomo dan S. P. S. Budhi. 1985. Pengaruh Perlakuan Alkali Terhadap Kecernaan In Vitro Bagasse. Proceeding Seminar Pemanfaatan Limbah Tebu Untuk Pakan Ternak. Grati. Hal : 144 147.

Tillman, A. D., H. Hartadi., S. Reksohadiprojo., S. Prawirokusumo dan S. Lebdosoekojo. 1991. Ilmu 
Makanan Ternak Dasar. Gadjah

Mada University Press, Yogyakarta.

Uden P. And P. J. Van Soest. 1984. Investigations of the in situ bag technique and comparidonof the fermentation in heifers, sheep, ponics and rabbits. J Amin. Sci. 58 : $213-221$.

Widiawati, Y., M. Winugroho dan E. Teleni. 2007. Perbandingan laju degradasi rumput gajah dan tanaman leguminosa di dalam rumen. Seminar Nasional Teknologi Peternakan Veteriner. Hal : 374379.

Wolayan, F.R. 1998. Pengaruh Fermentasi Bungkil Kelapa Menggunakan Trichoderma viride terhadap Komposisi Kimia dan Kecernaan Protein pada Ayam Broiler. Program Pascasarjana Unpad. Bandung. (Tesis Magister Sains). 